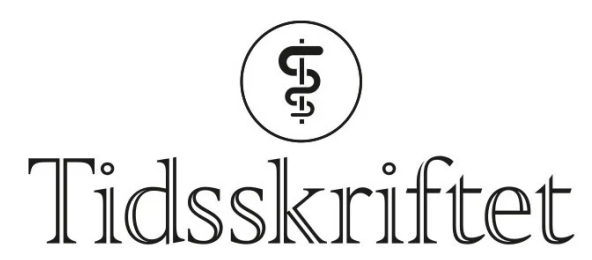

DEN NORSKE LEGEFORENING

\title{
Læren om det muliges kunst
}

\author{
ANMELDELSER
}

UNNIE HØIGAARD

Tidligere sjeflege ved Sunnaas sykehus, nå rådgivende lege i forsikring

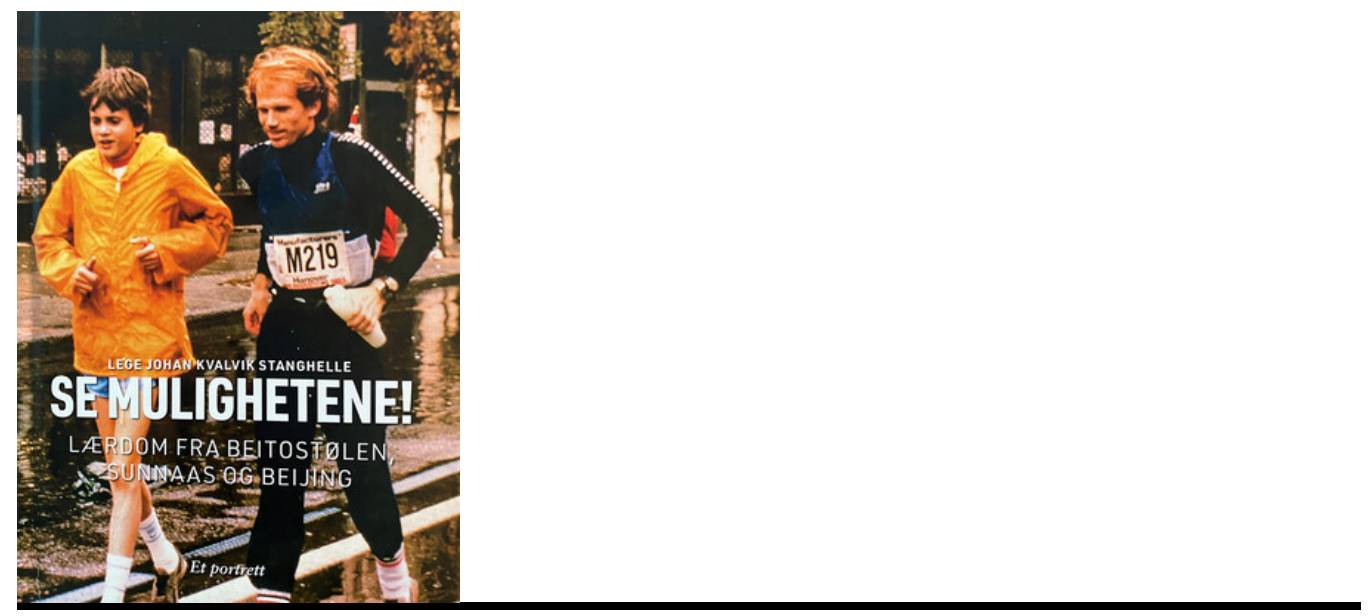

Kristin M. Hauge

Lege Johan Kvalvik Stanghelle - Se mulighetene!

Lærdom fra Beitostølen, Sunnaas og Beijing. Et portrett. 148 s, ill. Nesodden: JKS forlag, 2021. Pris NOK 300

ISBN 978-82-69237306

Kort fortalt har forfatteren gitt et portrett av kollega Johan Kvalvik Stanghelle, som før pensjonisttilværelsen reflekterer over sitt legeliv. Hva har vært drivkraften og inspirasjonen? Hva vil han gi til råd for den kommende generasjon av leger og andre som vil jobbe med rehabilitering?

Boka er innbundet, har et omfattende bildemateriale, og er lettfattelig og informativt skrevet med sine 148 sider. Boka er fint innpakket med personlige innblikk i Stanghelle sitt liv fra oppveksten på Nordmøre til livet på Nesodden i dag. Det er fin balanse mellom det faglige og det personlige, med morsomme og historiske eksempler fra det utradisjonelle legelivet. 
Norges første professor i spesialiteten fysikalsk medisin og rehabilitering utfordret den internasjonale ekspertisen i starten av legekarrieren med sine grensesprengende fors $ø \mathrm{k}$ med fysisk aktivitet for pasienter med cystisk fibrose, endog maratonløp. Den almene holdningen var at dette var kontraindisert og direkte farlig, men etterhvert ble det en vesentlig del av behandlingen.

Forfatter Kristin M. Hauge beskriver med god penn Stanghelles levende engasjement og utfordrende forskning innen rehabiliteringsfeltet, på tvers av fag, profesjon og landegrenser. Hans brennende interesse for internasjonalt samarbeid førte til en ledende posisjon i den store hjelpeaksjonen «Vennskapsskipet til Polen» i 1988, og han har demonstrert diplomatiske evner i et langvarig samarbeid med Kina og Russland, Palestina og Israel - og USA. Samtidig har han bygd opp Norges største forskningsmiljø innen rehabilitering ved Sunnaas sykehus. Stanghelle ble utnevnt til ridder av første klasse av Den Kongelige Norske St. Olavs Orden av H.M. Kong Harald i 2015 for sin mangeårige innsats i fagområdet fysikalsk medisin og rehabilitering.

Karrierens røde tråd har vært et fokus på muligheter og ikke begrensninger. Stanghelle poengterer i boken at det ikke bare handler om å drive fysisk aktivitet, men å kunne se hele mennesket og dets behov på alle områder. Hovedfokus er livskvalitet. Hvilke holdninger man selv har til mennesker med funksjonshemninger er vesentlig for å kunne gjøre en god jobb som fagperson - eller være en ressurs som venn, pårørende og medmenneske. Det er vanskelig å legge boka fra seg når en først begynner å lese. Selv leste jeg den fra perm til perm på en ettermiddag. Det var vel anvendt tid.

Publisert:3. mai 2021. Tidsskr Nor Legeforen. DOI: 10.4045/tidsskr.21.0134

(C) Tidsskrift for Den norske legeforening 2023. Lastet ned fra tidsskriftet.no 26. april 2023. 